Abstract-Residence times of individual fishes should reflect the durations over which habitat resources support survival, metabolic maintenance, and adequate growth. From May to October in 2006 and 2007, we measured residencies of ultrasonically tagged age-1+ Striped Bass (Morone saxatilis; $n=46)$, age- 0 and age- $1+$ Bluefish (Pomatomus saltatrix; $n=45$ and 35 ) and age-1+ Weakfish (Cynoscion rega$l i s ; n=41$ ) in a small estuarine tributary in New Jersey with 32 ultrasonic receivers to monitor movements and sensors to measure habitat resources. Striped Bass and age-1+ Bluefish used the estuary for medians of 9.5 days (d) $(\max =58 \mathrm{~d})$ and $22 \mathrm{~d}(\max =88 \mathrm{~d})$, and age- 0 Bluefish and Weakfish were resident for medians of $30 \mathrm{~d}(\max =52$ d) and $41 \mathrm{~d}(\max =88 \mathrm{~d})$, respectively. Small individuals $<500 \mathrm{~mm}$ TL were likely to remain in the estuary longer at warmer temperatures than were large individuals. Size-dependent temperature responses were similar to optimal temperatures for growth reported in previous studies. Freshwater discharge also influenced residence time. All species were likely to remain in the estuary until freshwater discharge rates fell to a value associated with the transition of the estuarine state from a partially to fully mixed state. This transition weakens flows into the upstream salt front where prey concentrations usually are high. Time of estuarine residence appeared to be regulated by temperatures that controlled scopes for growth and the indirect effects of freshwater discharge on prey productivity and concentration. Changes in the seasonal phenology of temperature, precipitation, and human water use could alter the durations over which small estuarine tributaries serve as suitable habitats.

Manuscript submitted 5 April 2013. Manuscript accepted 10 March 2014. Fish. Bull. 112:144-158 (2014). doi:10.7755/FB.112.2-3.4

The views and opinions expressed or implied in this article are those of the author (or authors) and do not necessarily reflect the position of the National Marine Fisheries Service, NOAA.

\title{
Residence time and habitat duration for predators in a small mid-Atlantic estuary
}

\author{
John P. Manderson (contact author) \\ Linda L. Stehlik \\ Jeff Pessutti \\ John Rosendale \\ Beth Phelan \\ Email address for the contact author: john.manderson@noaa.gov \\ Behavioral Ecology Branch \\ Northeast Fisheries Science Center \\ National Marine Fisheries Service, NOAA \\ James J. Howard Marine Sciences Laboratory \\ 74 Magruder Road \\ Highlands, New Jersey 07732
}

Temperate estuaries serve as spawning, nursery, and feeding habitats for many fishes and invertebrates during warmer months (Mann, 2000; Able, 2005; Able and Fahay, 2010). Warm temperatures, high nutrientstimulated primary and secondary productivity, and abundant spatial or structural refuges from predation enhance growth and survival. However, because estuaries are shallow, semi-enclosed bodies of water along the land-sea boundary, highfrequency atmospheric variability is rapidly translated into variability in biophysical processes that regulate the vital rates of species (e.g., water temperature, freshwater discharge, nutrient inputs, circulation and retention, and dissolved oxygen). Estuarine habitat suitability is, therefore, largely controlled by atmospheric and tidal forcing. As a result, estuarine habitat suitability is dynamic, and suitable habitats have temporal dimensions of timing and duration that are as important as the spatial dimensions of location and volume (Livingston, 1987; Manderson et al., 2002; Manderson et al., 2003; Manderson et al., 2006; Peterson et al., 2007).

Animals move in variable environments to fulfill requirements for survival, metabolic maintenance, growth, and reproduction and are believed to "climb" local fitness gradients that fall within their perceptual ranges (Armsworth and Roughgarden, 2005). Individual animals should minimize movement costs by becoming resident in suitable habitats until more costly long-distance movements are required by changes in habitat resources, such as temperature, oxygen concentrations, and concentrations of predators or prey or by life history event schedules. Changes in atmospheric forcing (e.g., air temperature and precipitation) that change both the timing and persistence of suitable shallow coastal habitats should affect the movement costs and energy budgets of the individual animals that use them. Because changes in atmospheric forcing and hydrography are coherent over spatial scales of 100 s to 1000 s of kilometers (Hare and Able, 2007; Manderson, 2008; Shearman and Lentz, 2010), effects on energy budgets of individual animals are likely to affect demographic rates at the population level.

In this study, we used passive ultrasonic biotelemetry and environmental monitoring to measure relationships of residence and egress of 3 predators-Striped Bass (age-1+ Morone saxatilis), Bluefish (age-0 
and age-1+ Pomatomus saltatrix) and Weakfish (age$1+$ Cynoscion regalis) - to habitat conditions in a small mid-Atlantic estuarine tributary that serves as a summer feeding and nursery ground. Individuals of these 3 species undertake broad-scale seasonal migrations of 100 s to 1000 s of kilometers along the Atlantic coast of the United States but can exhibit site fidelity in summer feeding and nursery habitats (Ng et al., 2007; Taylor et al., 2007; Pautzke et al., 2010; Turnure, 2010). They occupy upper trophic levels in mid-Atlantic estuarine food webs and are responsible for the transfer of nutrients and energy between benthic and pelagic compartments within estuaries and between estuaries and the coastal ocean (Hagy, 2002; Krause et al., 2003; Johnson et al., 2009).

We report on the seasonal and size-dependent patterns of residency of these predators in a small tributary (surface area of $\sim 1000$ ha) in New Jersey over 2 years. We use generalized additive mixed models to quantify size-dependent relationships of time of estuarine residence to water temperature and freshwater discharge. We assume that residency and flux rates of individuals through the estuary reflect the timings and durations when habitat resources support survival, metabolic maintenance, and at least adequate growth, except when emigration is triggered by changes in requirements associated with life-history-event schedules (e.g., timing of spawning) (Charnov, 1976; Winkler et al., 1995; Belisle, 2005).

\section{Materials and methods}

\section{Study area}

We performed acoustic biotelemetry in the Navesink River, New Jersey, a tributary of the Hudson-Raritan Estuary (Fig. 1), described in detail in other studies (Shaheen et al., 2001; Stoner et al., 2001; Scharf et al., 2004; Manderson et al., 2006). The Navesink River is nearly $1.5 \mathrm{~km}$ wide and extends $\sim 12 \mathrm{~km}$ east from its primary freshwater source, the Swimming River, to the Shrewsbury River and then to the Hudson-Raritan Estuary where it connects to the Atlantic Ocean. Salinities range from as low as $0.08 \%$ at the head of the Swimming River to $\sim 27 \%$ at the confluence of the Navesink and Shrewsbury rivers. The tidal range averages $1.4 \mathrm{~m}$. Tidal currents are flood dominated and attenuate in the middle and upper river, an area that is both deeper (mean depth $[\mu \mathrm{D}]=1.5 \mathrm{~m}$ mean low water $[\mathrm{MLW}]$; maximum of $\sim 9$ $\mathrm{m}$ ) and has sediments of finer grains than the lower river ( $\mu \mathrm{D}=1.0 \mathrm{~m} \mathrm{MLW}$; maximum of $\sim 6 \mathrm{~m}$ ) (Chant and Stoner, 2001; Fugate and Chant, 2005). The lower river has a complex network of channels flanked by sandbars and vegetated coves.

\section{Infrastructure of the estuarine observatory}

Fishes tagged with ultrasonic transmitters were detected with an array of omnidirectional receivers (model VR2, VEMCO ${ }^{1}$, Bedford, Canada) moored throughout the Navesink River from May 15 to October 3, 2006, and from April 18 to October 31, 2007 (Fig. 1). We attached receivers to anchored lines that had surface and subsurface floats. The subsurface floats suspended the receivers $\sim 80 \mathrm{~cm}$ above the bottom. In 2006, the array consisted of 27 receivers. In 2007, we moored 5 additional receivers in several marsh creeks and coves. Nearest neighbor distances between receivers in the river averaged $493 \mathrm{~m}$ (standard deviation $141 \mathrm{~m}$, within a range of $216-788 \mathrm{~m}$ ). On the basis of range tests, receivers moored in the middle and upper river had detection ranges of 350-600 m. Detection ranges were smaller and more variable in the lower river, which is topographically complex. The estuarine volume monitored by the array of all moored receivers was $\sim 1.397 \times 10^{7} \mathrm{~m}^{3}$ (surface area $=932 \mathrm{ha}$ ) at MLW. In 2006, the receivers were retrieved in September. We subsequently discovered that a few tagged fishes remained in the estuary after the receivers were retrieved. Therefore, in 2007 , receivers were left in place for an additional month.

We measured environmental variation with moored instruments and supplemental mobile surveys. The moored instruments provided measurements $\sim 12 \mathrm{~cm}$ above the bottom of the seafloor at 20-min intervals and included 3 Star-Oddi (Gardabaer, Iceland) temperature, salinity, and pressure sensors; 3 YSI, Inc. (Yellow Springs, Ohio) temperature, salinity, pressure, and dissolved oxygen sensors; and an Aanderaa RCM 9 (Aanderaa Data Instruments, Bergen, Norway) meter that measured current speed and direction, temperature, salinity, pressure, and optical backscatter. StarOddi sensors were used throughout the system (Fig. 1). YSI sensors were deployed in the upper river where episodes of low dissolved oxygen occur. We moored the RCM 9 in the channel that connects the lower and middle rivers. Weekly hydrographic surveys were performed from a 6-m vessel through the use of a Hydrolab DataSonde probe (Hach Hydromet, Loveland, CO) with temperature and salinity sensors mounted $0.5 \mathrm{~m}$ below the surface of the water and integrated with a GPS, and a Sea-Bird Electronics, Inc. (Bellevue, WA) SBE 25 Sealogger CTD with temperature, conductivity, pressure, dissolved oxygen, photosynthetically active radiation, turbidity, and fluorometer sensors. During each weekly survey, we performed cross-sectional transects of the river that intercepted all receiver moorings. The Hydrolab DataSonde and GPS continuously recorded temperate, salinity, and geographic position at 1-s intervals. Vertical profiles of the water column at each mooring were measured with the conductiv-

\footnotetext{
${ }^{1}$ Mention of trade names or commercial companies is for identification purposes only and does not imply endorsement by the National Marine Fisheries Service, NOAA.
} 


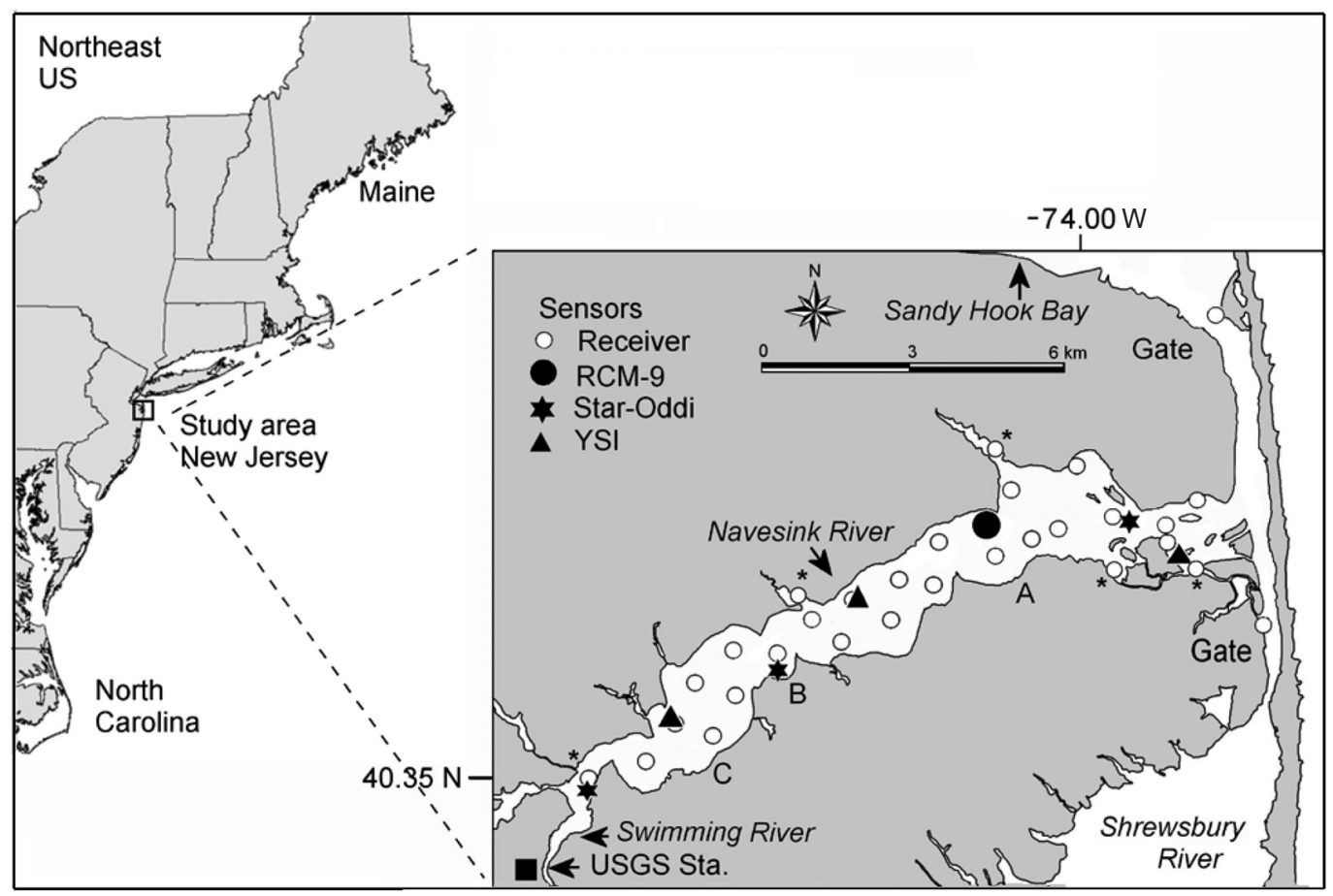

Figure 1

Map of the study area in the Navesink River, New Jersey, on the northeastern coast of the United States and the locations of the 32 moorings with ultrasonic receivers (white circles) and sensors (dark symbols) that measured the physical environment in the study area in which we captured, released, and monitored the movements of tagged Striped Bass (Morone saxatilis), Bluefish (Pomatomus saltatrix), and Weakfish (Cynoscion regalis) in 2006 and 2007 for a study of residence times and duration of habitat suitability for these 3 predators. The 5 moorings added in 2007 are indicated by asterisks. A, B and C labels indicate the locations referred to in the text and in the legend for Figure 2. Instruments deployed with receivers included temperature, salinity, pressure, and dissolved oxygen sensors from YSI, Inc., temperature, salinity, and pressure sensors from Star-Oddi, and an RCM-9 meter from Aanderaa Data Instruments that measured current speed and direction, temperature, salinity, pressure, and optical backscatter. Measurements of freshwater discharge were made at the U.S. Geological Survey (USGS) stream flow station in the Swimming River.

ity, temperature, and depth (CTD) sensor. In 2007, we performed additional hydrographic surveys associated with gillnet surveys of predators and prey in the upper river.

Measurements of freshwater discharge (in meters per second) from the Swimming River were made at the U.S. Geological Survey stream flow station (http://nwis.waterdata.usgs.gov/nj/nwis/uv/?site no $=01407500 \&$ PARAmeter_cd $=00065,00060)$. Barometric pressures, wind, and air temperatures were measured $7.5 \mathrm{~km}$ from the study area at the NOAA weather station in Sandy Hook, New Jersey (http:// www.ndbc.noaa.gov/station_page.php?station=sdhn4).

\section{Ultrasonic tagging}

From May 14 to September 8, 2006 and from May 1 to October 2, 2007, we used hook and line to capture age$1+$ Striped Bass, age- 0 and age-1+ Bluefish, and age-1+ Weakfish as seasonally available within the footprint of the estuarine observatory (Table 1 ). On the basis of published age-length relationships, we divided Bluefish into age- 0 and age- $1+$ age classes at a total length of $290 \mathrm{~mm}$ (Chiarella and Conover, 1990; Munch and Conover, 2000; Scharf et al., 2004). We transported fishes to the James J. Howard Marine Sciences Laboratory in Highlands, New Jersey, for internal tagging. Fishes were held $\leq 8$ days (d) in tanks (2.5-m diameter, 0.35-m depth) supplied continuously with ambient estuarine water. We anaesthetized fishes with AquiS (AquiS New Zealand, Ltd., Lower Hutt, New Zealand) at a concentration of $54 \mathrm{mg} / \mathrm{L}$. Duration of anesthesia averaged $\sim 3 \mathrm{~min}$.

After a fish was anaesthetized, we made an incision $1-2 \mathrm{~cm}$ long on its ventral midline and inserted into the body cavity a sterilized, uniquely coded ultrasonic transmitter (V9-6L with a frequency of $69 \mathrm{kHz}$, repetition rate of $40-120 \mathrm{~s}$, dimensions of $9 \mathrm{~mm} \times 20 \mathrm{~mm}$, weight of $2 \mathrm{~g}$ in water, and minimum battery life of 110 d; VEMCO). We closed incisions with 2 or 3 nylon sutures (Ethilon 30 and 40 with FS1 cutting needle, Ethi- 


\section{Table 1}

Median (Md) total lengths (TL) in millimeters, number of fish released, release dates, median number of detections, and median residence times (in days) of fishes released in 2006 and 2007with ultrasonic transmitters in the Navesink River, New Jersey, for a study of residence times and habitat duration of 3 predators: age-1+ Striped Bass (Morone saxatilis), age- 0 and age-1+ Bluefish (Pomatomus saltatrix), and age-1+ Weakfish (Cynoscion regalis). Median days detected (i.e., residence time in days) and confidence limits (CL) were calculated with right-censored Kaplan-Meier survival analysis (see Fig. 3). Significant Spearman's rank correlation coefficients $(\rho)$ between release day and body length are shown in bold type. An asterisk (*) denotes that fishes caught by anglers before egress or detected by receivers on the last fall day of the experiment were censored (Striped Bass=1, age-0 Bluefish=4, age-1+ Bluefish=1, and Weakfish=1).

\begin{tabular}{|c|c|c|c|c|c|c|c|}
\hline $\begin{array}{l}\text { Species-and- } \\
\text { age class }\end{array}$ & Year & $\begin{array}{l}\text { Md TL } \\
\text { (Range) }\end{array}$ & $\begin{array}{l}\text { Number } \\
\text { released }\end{array}$ & $\begin{array}{c}\text { Release } \\
\text { dates }\end{array}$ & $\begin{array}{c}\text { Release date } \\
\text { vs. length } \\
\text { Spearman's } \rho, \\
P \text {-value }\end{array}$ & $\begin{array}{c}\text { Md number } \\
\text { of detections } \\
\quad \text { (range) }\end{array}$ & $\begin{array}{c}\text { Md days } \\
(95 \% \mathrm{CL}) \\
\text { (range) }\end{array}$ \\
\hline \multirow[t]{2}{*}{ Striped Bass } & 2006 & $\begin{array}{c}465 \\
(359-630)\end{array}$ & 34 & 15May-28Jun & $0.41,0.016$ & $\begin{array}{c}2475 \\
(343-20331)\end{array}$ & $\begin{array}{l}16(9,28) \\
\left(2-58^{*}\right)\end{array}$ \\
\hline & 2007 & $\begin{array}{c}442 \\
(342-510)\end{array}$ & 12 & 3May-19Jun & $0.76,0.004$ & $\begin{array}{c}1469 \\
(22-3440)\end{array}$ & $8(7, \infty)(2-50)$ \\
\hline \multirow[t]{2}{*}{ Age-1+ Bluefish } & 2006 & $\begin{array}{c}335 \\
(310-390)\end{array}$ & 14 & 5Jun-16Aug & $0.45,0.107$ & $\begin{array}{c}5428 \\
(311-17586)\end{array}$ & $\begin{array}{c}19(16,42) \\
(10-48)\end{array}$ \\
\hline & 2007 & $\begin{array}{c}455 \\
(310-610)\end{array}$ & 21 & 1May-19Jun & $-0.83,<0.001$ & $\begin{array}{c}3543 \\
(60-21174)\end{array}$ & $\begin{array}{l}29(20,46) \\
(3-88)\end{array}$ \\
\hline \multirow[t]{2}{*}{ Age-0 Bluefish } & 2006 & $\begin{array}{c}210 \\
(175-270)\end{array}$ & 15 & 27Aug-9Sep & $0.68,0.005$ & $\begin{array}{c}2503 \\
(291-7889)\end{array}$ & $\begin{array}{c}29(21, \infty) \\
\left(5-37^{*}\right)\end{array}$ \\
\hline & 2007 & $\begin{array}{c}246 \\
(222-275)\end{array}$ & 30 & 29Aug-21Sep & $0.28,0.140$ & $\begin{array}{c}1706 \\
(101-6777)\end{array}$ & $\begin{array}{c}29(22,37) \\
\left(1-52^{*}\right)\end{array}$ \\
\hline \multirow[t]{2}{*}{ Weakfish } & 2006 & $\begin{array}{c}337 \\
(224-535)\end{array}$ & 15 & 13Jul-16Aug & $0.32,0.244$ & $\begin{array}{c}4040 \\
(41-16568)\end{array}$ & $\begin{array}{c}33(22, \infty) \\
\left(4-64^{*}\right)\end{array}$ \\
\hline & 2007 & $\begin{array}{c}389 \\
(304-500)\end{array}$ & 26 & 29Jun-9Oct & $-0.42,0.034$ & $\begin{array}{c}1708 \\
(31-11391)\end{array}$ & $\begin{array}{c}47(35,70) \\
\left(6-88^{*}\right)\end{array}$ \\
\hline
\end{tabular}

con, Somerville, NJ). We measured the total length (TL) of each fish in millimeters and inserted unique anchor tags into the dorsal muscle. Fishes recovered from anaesthesia in $\leq 9$ min and were monitored for 2-48 hours in flow-through laboratory tanks. We released fishes in good condition at randomly selected locations in the river. This random release approach was used to monitor initial patterns of habitat selection during the first 24-48 hours. We released $\leq 5$ individuals of each age class for each species per week to observe movements over the broadest range of environmental conditions.

Striped Bass, Weakfish, and age-1+ Bluefish $(n>12$ for all classes) implanted with replica transmitters survived $>120 \mathrm{~d}$ in the laboratory (B. Phelan and J. Rosendale, unpubl. data). Several age-0 Bluefish $<170$ $\mathrm{mm}$ TL died after implantation of replica transmitters. We, therefore, released only Bluefish $>175 \mathrm{~mm}$ TL with active transmitters in the field.

\section{Analyses}

In this investigation, we analyzed predator residence times in and egress from the estuarine tributary rather than movements within the tributary. We eliminated data from 2 tagged fishes whose movement trajectories indicated that they died shortly after release. Then, we aggregated data collected at all receivers to calculate the presence or absence of each fish in the estuary for each day of observation. Individuals detected in the lower estuary and subsequently not detected for $24 \mathrm{~h}$ were considered absent. Several fishes detected at the upstream receiver in the Swimming River disappeared for a short time and then were detected in the Swimming River or upper Navesink River. We assumed these fishes had spent that time upstream of the receiver array and, therefore, had remained in the estuary. We performed all analyses with $\mathrm{R}$ software ( $\mathrm{R}$ Core Team, 2013).

We estimated the number of days that tagged fishes used the estuary with right-censored Kaplan-Meier survival analysis (Bennetts et al., 2001). We censored 5 age- 0 Bluefish and 1 Striped Bass detected in the estuary when receivers were removed in the fall, and 1 Weakfish caught by an angler in the Navesink River. In survival analysis, observations are censored when the study ends before the event response occurs (in this case, egress) or when an individual is removed from the study (e.g., dies) before the event response occurs. 


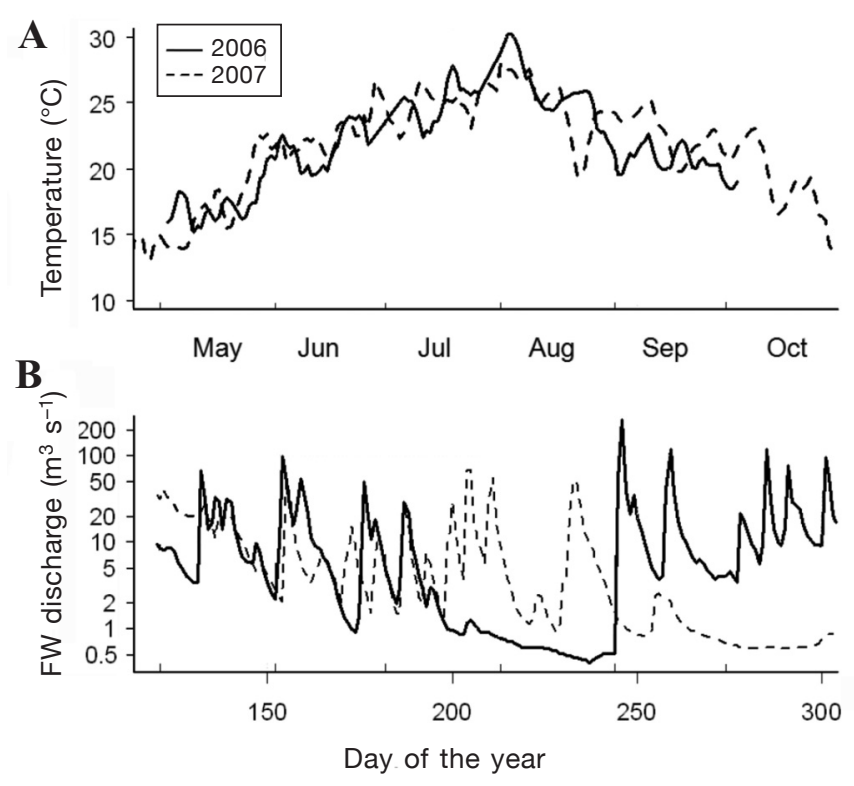

Figure 2

For a study of residence times and habitat duration of Striped Bass (Morone saxatilis), Bluefish (Pomatomus saltatrix), and Weakfish (Cynoscion regalis) in 2006 and 2007, mean daily (A) temperatures were measured at the RCM 9 sensor mooring in the Navesink River and (B) freshwater (FW) discharge rates ( $y$-axis on log scale) were measured at a U.S. Geological Survey stream flow station in the Swimming River. For locations of the mooring and flow station, see Figure 1.
Because the presence-absence data were serially correlated in time for each individual fish, errors were modeled as a first-order autoregressive process nested within each individual fish. Release date and year also were considered as model covariates.

Preliminary models were made with smoothing splines, and covariates were chosen through the use of manual backward selection, analysis of partial deviance, and Akaike's information criterion (AIC) (Wood, 2006). To avoid over-fitting smooths, we set gamma to 1.4 and the basis dimension $(k)$ to 5 , limiting the maximum degrees of freedom of the smooths to 4. A covariate was removed from the model if its smoother was statistically insignificant, the change in AIC was $>0$ when the variable was removed, or 2 standard error confidence bands in the deviance plots included zero throughout variable domain. Covariates with equivalent degrees of freedom $\approx 1$ were tested as linear effects before they were eliminated on the basis of these criteria. We used tensor product smooths, which are appropriate when covariates are measured on different scales, to test 2 -way interactions between body sizes and other significant covariates (Wood, 2006). Because the response of age-1+ Bluefish to temperature was strongly discontinuous across body sizes (i.e., lengths) at $\sim 500 \mathrm{~mm}$ TL, we pooled individuals into 2 bodysize classes (300-500 mm TL, >500 mm TL) and treated body size as a factor covariate.
We used log-rank tests for differences in "residency" curves between the species-and-age classes and years (Harrington and Fleming, 1982).

We examined relationships between the presence of individuals in each age class of each tagged species in the estuary and environmental variation with logistic generalized additive mixed models (GAMM) in the gamm4 library in R (Aarts et al., 2008; Wood, 2012). We limited final analyses to body size and the environmental variables of water temperature and freshwater discharge, which are important drivers of the estuarine habitat suitability. Other measured environmental variables were correlated with temperature and freshwater discharge and had lower explanatory power in preliminary models. In addition, the time series for salinity and oxygen in the estuary were incomplete. Finally, complex preliminary GAMMs with more than a few variables also failed to converge.

We analyzed water temperatures measured at the RCM 9 mooring and daily freshwater discharge (cubic meters per second) measured in the Swimming River because they were the most complete and accurate time series. We log transformed freshwater discharge values, which were strongly leptokurtic. Individual fish was considered as the random effect in all models.

\section{Results}

\section{Patterns of temperature and freshwater discharge}

Spring and summer of 2006 were hotter and drier than those seasons in 2007 (Fig. 2, A and B). In 2006, spring warming rates were slightly higher and, in late Julyearly August, temperatures exceeded $30.0^{\circ} \mathrm{C}(2006$ $\left.\max =30.2^{\circ} \mathrm{C} ; 2007 \max =28.0^{\circ} \mathrm{C}\right)$. During the autumn, however, temperatures were cooler in 2006 than in 2007. Discharge in the Swimming River was high during the spring of both years. Freshwater discharge was low $\left(<2 \mathrm{~m}^{3} \mathrm{~s}^{-1}\right)$ and discharge events were relatively rare from mid-July through August 2006. In 2007, periods of low discharge occurred briefly (2-3 d) once in July and twice in August. Discharge was low throughout much of the fall of 2007, in contrast to several episodes of high river discharge that were produced by frequent rains during the autumn of 2006.

\section{Patterns of release}

The species-and-size classes were available for collection and release during different periods of time (Table 1). Striped Bass were released in May and June. We released age-1+ Bluefish from May to July, but large 


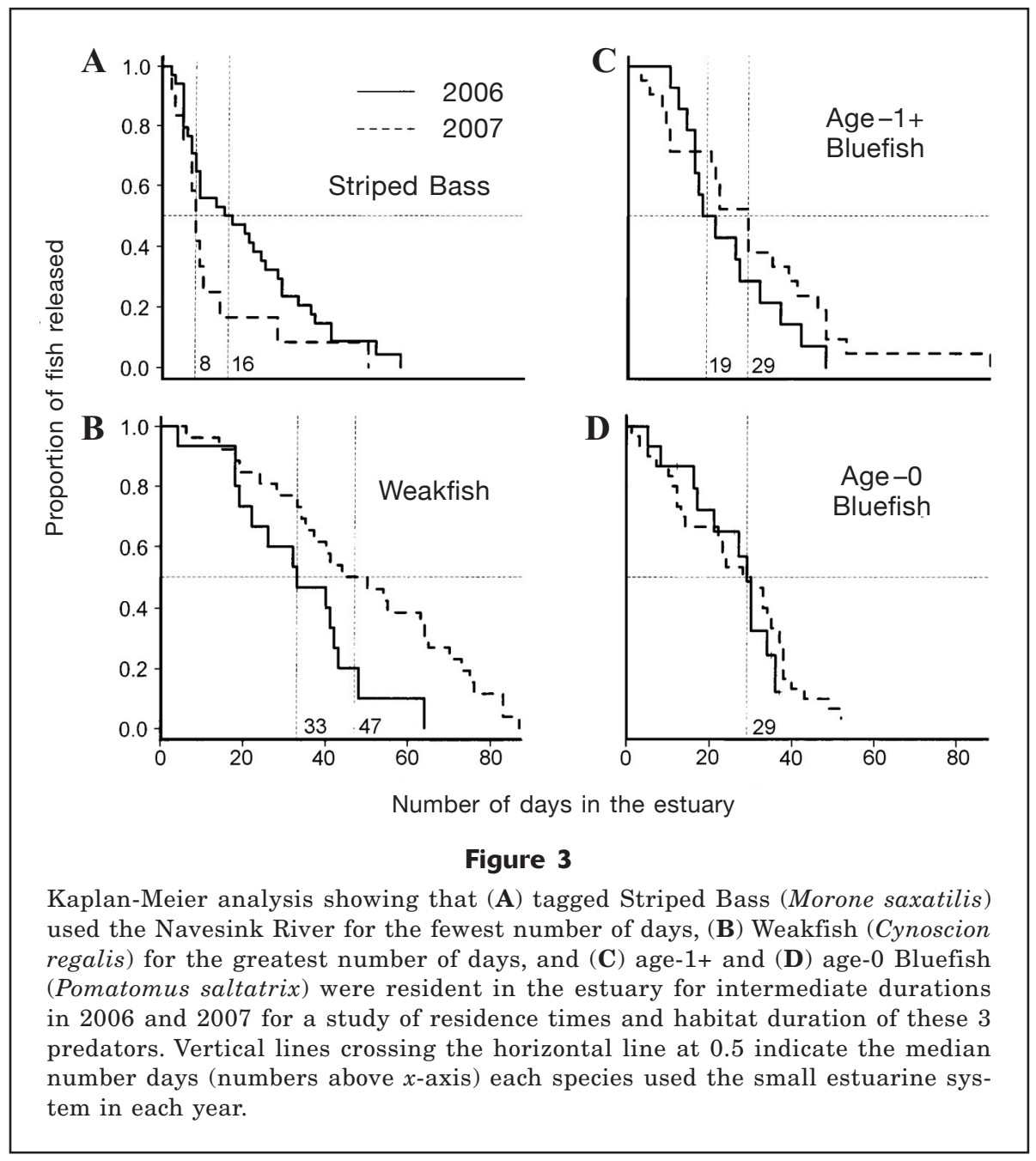

individuals $>500 \mathrm{~mm}$ TL were released in May and early June. We released age-0 Bluefish >175 mm TL in August and September. Weakfish were available for release from late June to mid-September.

Release date and body size covaried for each age class of each species during at least one year (Table 1). Smaller fishes were generally available for earlier release. However, in 2007, large age-1+ Bluefish and Weakfish were released earlier than smaller individuals.

\section{Patterns of egress}

Although most of the tagged fishes remained in the Navesink River until final egress, several individuals of all age classes of tagged species made temporary excursions out of the estuary for a period $\geq 3 \mathrm{~d}$. More than half of the Striped Bass that we released in 2006 left the estuary temporarily and returned after absences of $3-53 \mathrm{~d}(n=18$; mean excursion $[\mu]=15.6 \mathrm{~d})$. In 2007 , only $25 \%$ of the tagged Striped Bass made temporary excursions $(n=3, \mathrm{~m}=15.6 \mathrm{~d}, \max =33 \mathrm{~d})$. Several Striped Bass made 2 or more excursions $(n=7, \max =6 \mathrm{~d})$. Three fish that left the estuary in June or July 2006 returned in late August or September after absences $\geq 50 \mathrm{~d}$.

Weakfish and Bluefish showed stronger fidelity to the estuarine tributary than Striped Bass. More than $74 \%$ of the Weakfish and age-1+ Bluefish that we released remained in the estuary until final egress. Temporary excursions of these fishes (Bluefish $n$ : 2006=4, 2007=5; Weakfish $n: 2006=5,2007=6)$ lasted $2-52 \mathrm{~d}(\mu=\sim 15 \mathrm{~d})$. In 2006, Bluefish and Weakfish left the estuary temporarily during the period of late July-early August when temperatures exceeded $28^{\circ} \mathrm{C}$ and freshwater discharge was low (Fig. 2). In 2007, age-1+ Bluefish made excursions outside the estuary in late June-early July, and Weakfish made them throughout the summer. Age-0 Bluefish rarely left the tributary before final egress ( $n$ : $2006=1,2007=3 ; \mathrm{m}=10 \mathrm{~d}$; range: $4-19$ d).

\section{Duration of estuarine habitat use}

The species and size classes remained in the estuary for different lengths of time $\left(\chi^{2}=40.4, \mathrm{df}=7, P<0.001\right.$; 


\section{Table 2}

Results from log-rank tests in the Grho family of statistics used to examine differences between "residency curves" derived from Kaplan-Meier survival analysis $\left(\chi^{2}=40.4, \mathrm{df}=7, P=1.07 \mathrm{e} 06\right.$; see Fig. 3$)$ for fishes tagged with acoustic transmitters and released in the Navesink River, New Jersey, in 2006 and 2007 for a study of residence times and duration of habitat suitability for 3 predators: age-1+ Striped Bass (Morone saxatilis), age- 0 and age-1+ Bluefish (Pomatomus saltatrix), and age-1+ Weakfish (Cynoscion regalis). Analysis used year and species-and-age class as predictors. V=Variance.

\begin{tabular}{lcccccc}
\hline Species & Year & Number & Observed (O) & Expected $(\mathrm{E})$ & $(\mathrm{O}-\mathrm{E})^{2} / \mathrm{E}$ & $(\mathrm{OE})^{2} / \mathrm{V}$ \\
\hline Age-0 Bluefish & & & & & & \\
& 2006 & 15 & 11 & 10.21 & 0.0606 & 0.0688 \\
Age-1+ Bluefish & 2007 & 30 & 29 & 25.32 & 0.5350 & 0.6775 \\
& 2006 & 14 & 14 & 9.90 & 1.6978 & 1.9043 \\
Striped Bass & 2007 & 21 & 21 & 22.39 & 0.0869 & 0.1109 \\
& 2006 & 34 & 33 & 21.05 & 6.7900 & 8.2661 \\
Weakfish & 2007 & 12 & 12 & 4.41 & 13.0586 & 14.1044 \\
& 2006 & 15 & 14 & 16.64 & 0.4175 & 0.4900 \\
& 2007 & 26 & 26 & 50.08 & 11.5787 & 20.9341 \\
\end{tabular}

Fig. 3, A-D, Tables 1 and 2). Smaller individuals (300$500 \mathrm{~mm}$ TL) of all species were more likely to have longer residence times than larger fishes. Striped Bass typically used the system for the fewest number of days. Weakfish had the longest residencies.

Striped Bass used the estuary for a median of 16 d in 2006 and of $8 d$ in 2007. This difference was not, however, statistically significant because of the small sample size in $2007\left(\chi^{2}=2.5, \mathrm{df}=1, P=0.1120\right)$. All Striped Bass $>485 \mathrm{~mm}$ TL used the estuary less than 24 d. Many smaller fish had longer residencies $(n=24)$ and some of them $(n=4)$ used the estuary $\geq 50 \mathrm{~d}$.

Median residency periods for age-1+ Bluefish were $19 \mathrm{~d}$ in 2006 and $29 \mathrm{~d}$ in 2007, but the interannual difference was not significant $\left(\chi^{2}=1.3, \mathrm{df}=1, P=0.248\right)$. Several age-1+ Bluefish $<500 \mathrm{~mm}$ TL $(n=8)$ used the estuary $>40 \mathrm{~d}$. Age-0 Bluefish used the system for a median of $29 \mathrm{~d}$, and distributions of residencies were nearly identical in the 2 years of this study $\left(\chi^{2}=0.2\right.$, $\mathrm{df}=1, P=0.651)$. Age-0 fish remained in the river for as long as $52 \mathrm{~d}(n=2)$. Residencies of tagged age- 0 and age-1+ Bluefish were not statistically different $\left(\chi^{2}=1.8\right.$, $\mathrm{df}=3, P=0.625$ ). However, we were unable to tag age- 0 fish $<175 \mathrm{~mm}$ TL that occurred in the Navesink River as early as June (senior author, unpubl. data), and receivers were removed before the final egress of several tagged age- 0 individuals ( $n: 2006=4,2007=1$ ). Therefore, age-0 Bluefish probably used the system much longer than age-1+ fish.

Weakfish remained in the estuary for a median of 33 $\mathrm{d}$ in 2006 and $47 \mathrm{~d}$ in $2007\left(\chi^{2}=5.6, \mathrm{df}=1, P=0.02\right)$. Residencies may have been longer in 2007 because, during that year, Weakfish were released earlier and the observation period was longer. All Weakfish $<400 \mathrm{~mm}$ TL
( $n=18$ ) used the estuary $\geq 40 \mathrm{~d}$ and 10 individuals were resident $>60 \mathrm{~d}$.

\section{Effects of environmental variables and body size on residence and egress}

Smaller individuals of all 3 species tended to remain in the estuary at warmer temperatures than those preferred by larger individuals (Table 3, Fig. 4). Size-dependent temperature responses were continuous for Striped Bass and Weakfish but discontinuous for Bluefish. On average, Striped Bass were more likely to leave the system when temperatures exceeded $23^{\circ} \mathrm{C}$ than when cooler temperatures occurred (Fig. 4A). However, temperature effects were greater for larger Striped Bass, which left rapidly as temperatures warmed in the early summer. In contrast, smaller fish were more likely to remain in the system into the summer when temperatures were relatively warm. Large Bluefish released in early summer were also likely to emigrate from the estuary when temperatures increased above $23^{\circ} \mathrm{C}$ (Fig. 4C). In contrast, smaller age-1+ Bluefish were likely to be present when temperatures were warmer (Fig. 4D). Age0 Bluefish were likely to remain in the estuary when temperatures were warmest. It was unlikely for age-0 Bluefish to leave until autumn temperatures fell below $\sim 20.5^{\circ} \mathrm{C}$ (Fig. $4 \mathrm{E}$ ). Weakfish were resident in the estuary at the warmest temperatures and were likely to leave the estuary when temperatures cooled below $23^{\circ} \mathrm{C}$ (Fig. 4B). Larger Weakfish emigrated at slightly higher temperatures than smaller fish.

All 4 species-and-age classes were more likely to leave the estuary when the Swimming River dis- 
Table 3

Results from the final generalized additive mixed models of effects of body size, estuarine temperature, and freshwater discharge (FW) on the residence time of ultrasonically tagged Striped Bass (Morone saxatilis), Bluefish (Pomatomus saltatrix; age-0 and age-1+), and Weakfish (Cynoscion regalis) released into the Navesink River, New Jersey, in 2006 and 2007 (see Figs. 4 and 5 for deviance plots). Individual fish was included as a random effect (i.e., intercept) in all models. Temporal autocorrelation in detections was considered as a first-order, autoregressive process that occurred within each fish. The independent variables included in initial models were year as a factor, as well as release day, body length, temperature, and freshwater discharge, all of which were first considered with cubic smoothing splines (s) with a maximum of 4 degrees of freedom. Tensor product smooths (t2) were used to model interactions. Variables were included as linear effects if expected degrees of freedom (EDF) of splines were close to 1, and they were eliminated from models when they did not contribute to a reduction in Akaike's information criterion (AIC). Body length (total length in millimeters) was considered as a class variable in modeling the temperature response of age-1+ Bluefish because the length $\times$ temperature interaction was strongly discontinuous.

\begin{tabular}{|c|c|c|c|c|c|}
\hline Species and Parametric coefficient & Estimate & SE & $Z$-value & $P$-value & $\mathrm{AIC}$ \\
\hline $\begin{array}{c}\text { Striped Bass } \\
\text { Intercept }\end{array}$ & -2.778 & 0.177 & -15.73 & $<0.0001$ & 4354 \\
\hline $\begin{array}{l}\text { Approximate significance of nonparametric terms } \\
\text { t2 (Temperature, body length }) \\
\mathrm{s}(\log (F W \text { Discharge }+1)) \\
\mathrm{s}(\text { Release day }) \\
\text { Coefficient of multiple determination }\left[R^{2}\right]=0.15\end{array}$ & $\begin{array}{r}\mathrm{EDF} \\
16.678 \\
3.898 \\
2.925\end{array}$ & $\begin{array}{r}\chi^{2} \\
228.65 \\
201.90 \\
29.66\end{array}$ & & $\begin{array}{l}<0.0001 \\
<0.0001 \\
<0.0001\end{array}$ & $\begin{array}{l}4111 \\
3888 \\
3844\end{array}$ \\
\hline $\begin{array}{l}\text { Age-1+ Bluefish } \\
\text { Intercept } \\
\text { Year }\end{array}$ & $\begin{array}{l}-1.739 \\
-1.055\end{array}$ & $\begin{array}{l}0.376 \\
0.473\end{array}$ & $\begin{array}{l}-4.626 \\
-2.230\end{array}$ & $\begin{array}{r}<0.0001 \\
0.0257\end{array}$ & $\begin{array}{l}4301 \\
4309\end{array}$ \\
\hline $\begin{array}{l}\text { Approximate significance of nonparametric terms } \\
\mathrm{s}(\text { Temperature }) \text { Length }<500 \mathrm{~mm} \\
\mathrm{~s}(\text { Temperature }) \text { Length }>500 \mathrm{~mm} \\
\mathrm{~s}(\log (F W \text { Discharge }+1)) \\
\mathrm{s}(\text { Release day }) \\
R^{2}=0.264\end{array}$ & $\begin{array}{l}\text { EDF } \\
3.927 \\
2.970 \\
3.893 \\
1.958\end{array}$ & \begin{tabular}{r}
\multicolumn{1}{c}{$\chi^{2}$} \\
286.79 \\
193.74 \\
418.689 \\
9.362
\end{tabular} & & $\begin{array}{r}<0.0001 \\
<0.0001 \\
<0.0001 \\
0.0088\end{array}$ & $\begin{array}{l}3700 \\
\\
3122 \\
3120\end{array}$ \\
\hline $\begin{array}{l}\text { Age-0 Bluefish } \\
\text { Intercept } \\
\log (F W \text { Discharge }+1)\end{array}$ & $\begin{array}{l}0.861 \\
0.922\end{array}$ & $\begin{array}{l}0.550 \\
0.171\end{array}$ & $\begin{array}{l}1.566 \\
5.385\end{array}$ & $\begin{array}{r}0.1170 \\
<0.0001\end{array}$ & $\begin{array}{l}1974 \\
1900\end{array}$ \\
\hline $\begin{array}{l}\text { Approximate significance of nonparametric terms } \\
\mathrm{s}(\text { Temperature }) \\
R^{2}=0.235\end{array}$ & $\begin{array}{l}\mathrm{EDF} \\
3.345\end{array}$ & $\begin{array}{c}\chi^{2} \\
330.9\end{array}$ & & $<0.0001$ & 1128 \\
\hline $\begin{array}{l}\text { Weakfish } \\
\text { Intercept } \\
\text { Year } \\
\text { Release day }\end{array}$ & $\begin{array}{r}-16.980 \\
2.484 \\
0.079\end{array}$ & $\begin{array}{l}4.714 \\
1.049 \\
0.022\end{array}$ & $\begin{array}{r}-3.602 \\
2.367 \\
3.555\end{array}$ & $\begin{array}{l}0.0179 \\
0.0257 \\
0.0004\end{array}$ & $\begin{array}{l}3731 \\
3729 \\
3727\end{array}$ \\
\hline $\begin{array}{l}\text { Approximate significance of terms } \\
\mathrm{t} 2(\text { Temperature }, \text { Body length }) \\
\mathrm{s}(\log (\text { FW Discharge }+1)) \\
R^{2}=0.368\end{array}$ & $\begin{array}{r}\text { EDF } \\
12.413 \\
3.865\end{array}$ & $\begin{array}{c}\chi^{2} \\
580.5 \\
131.0\end{array}$ & & $\begin{array}{l}<0.0001 \\
<0.0001\end{array}$ & $\begin{array}{l}2060 \\
1932\end{array}$ \\
\hline
\end{tabular}

charge fell below $\sim 2 \mathrm{~m}^{3} \mathrm{~s}^{-1}$ than when discharge was higher (Table 3, Fig. 5). This effect was evident when we included year as a factor and when we modeled years separately. As a result, the response to low discharge did not appear to be related to interannual differences in sample size or freshwater discharge. Striped Bass were also likely to leave the tributary during episodes of high freshwater discharge $\left(>50 \mathrm{~m}^{3}\right.$ $\mathrm{s}^{-1}$; Fig. 5A). Age-0 Bluefish and Weakfish were best modeled with linear discharge terms, indicating that the animals were not likely to leave the estuary during periods when freshwater discharge was high (Fig. 5, $\mathrm{B}$ and $\mathrm{C}$ ).

There were significant differences in patterns of residency among individual fishes (random intercept; Table 3). Furthermore, the year effect was significant in GAMMs for Striped Bass, Weakfish, and age-1+ Bluefish, consistent with descriptions in the previous section, under Patterns of egress. Release date was significant in the models for Striped Bass, Weakfish, and age-1+ Bluefish. 


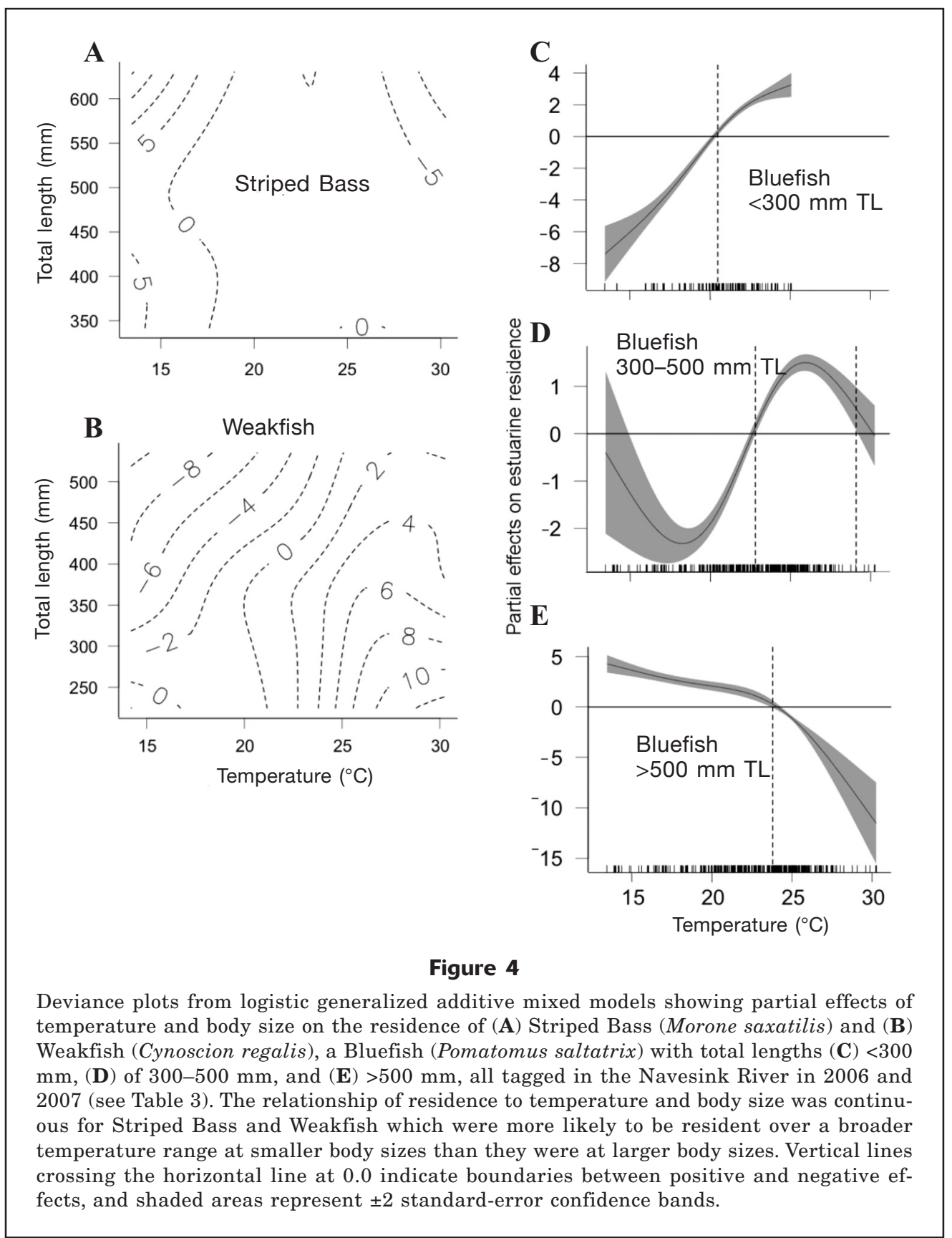

The fish that were released later in the season typically were small and generally had longer residencies.

\section{Discussion}

Our observations of estuarine residency for individual Striped Bass, Bluefish, and Weakfish indicate that small ( 1000 ha), mid-Atlantic estuarine tributaries, such as the Navesink River, contain habitat resources necessary to support survival and adequate growth of age-0 and age- 1 individuals for relatively long periods of time during the summer months. Of the age-1+ Striped Bass that we tagged, 25\% used the river for more than $26 \mathrm{~d}$, and the same fractions of the Bluefish (age 1 and 0 ) and age-1+ Weakfish that we tagged used the system for more than 36 and $62 \mathrm{~d}$. Earlier investigations that used fortnightly gillnet surveys of the Navesink River and adjacent Sandy Hook Bay indicated that these 3 predators are abundant in the system, which they use as a feeding habitat, nursery habitat, or both (Scharf et al., 2004; Manderson et al., 2006). Our 


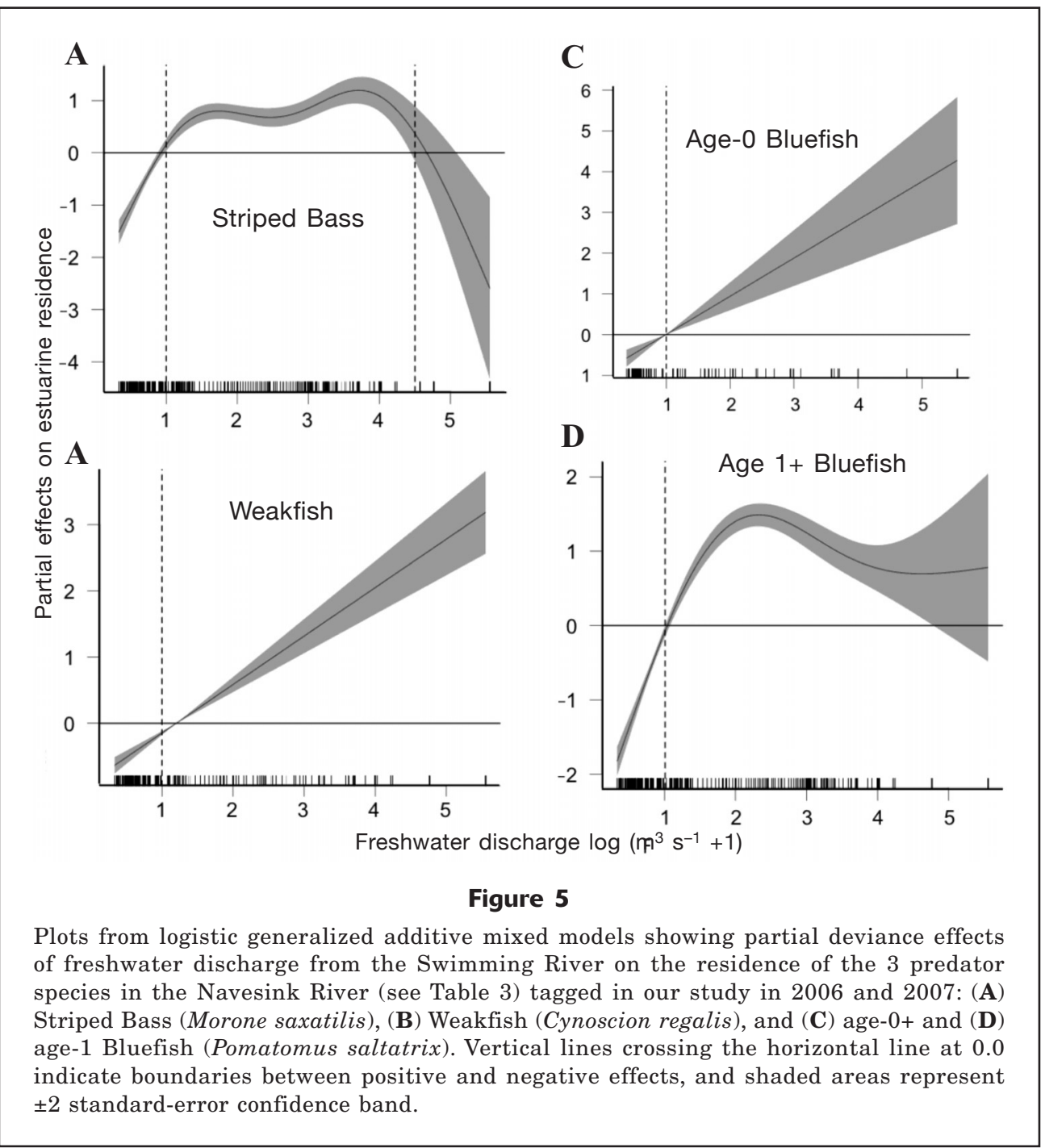

telemetry study indicates that high abundances reflect relatively long-term residence times for predators $<500$ $\mathrm{mm}$ TL rather than a rapid flux of many transient individuals through the ecosystem. Long-term residences of individual fishes with little straying indicates that temperature, oxygen, and prey resources persist at suitable levels in the small tributary for relatively long periods.

Predators with small body sizes had longer residencies and, therefore, appeared to be supported longer by habitat resources in the small ecosystem than were larger individuals. Large Striped Bass and Bluefish ( $>500 \mathrm{~mm}$ TL) used the tributary for a few days to a few weeks during the spring. Large Weakfish (>400 mm TL) released later in the summer were also relatively transient. Smaller age-1+ Bluefish remained in the estuary for intermediate lengths of time. Finally, age- 0 Bluefish and small age-1+ Weakfish $(<400 \mathrm{~mm}$ TL) had the longest residence times (median residence $=29 \mathrm{~d}$ and $\sim 40 \mathrm{~d})$ that were probably underestimated in our study. Although Weakfish were common in gill nets in May (L. Stehlik and senior author, unpubl. data), we were able to capture them only with hook and line in early July after their diets had shifted from invertebrate to fish prey. Small Bluefish (20-30 mm TL), which cannot be surgically tagged, are collected in Navesink River as early as June in beach seines and fine mesh gillnets (L. Stehlik, unpubl. data). Small Weakfish and Bluefish were, therefore, resident in the Navesink River probably for much longer periods than those that we measured. Our observations of long residences of small predator cohorts in the Navesink River are consistent with observations made in larger estuarine ecosystems (Grothues and Able, 2007; Taylor et al., 2007; Wingate and Secor, 2007; Mather et al., 2009; Turnure, 2010).

The size-dependent patterns of estuarine residence time for the 3 studied predators may have been related to size-dependent requirements for prey resources. 
Metabolic rates of animals generally scale with body mass to approximately the $3 / 4$ power (Anderson-Teixeira et al., 2009; and references therein; note that in our study we were concerned with resource requirements of individual whole fish that influence residency, not with mass-specific metabolic rates). Therefore, larger or older individuals require more prey resources per unit of energy cost of prey acquisition (i.e., search, capture, handling time, and digestion) than do smaller predators to meet metabolic demand at a given temperature. Prey resources in the Navesink River include large numbers of small invertebrates and fishes, such as age-0 Atlantic Menhaden (Brevoortia tyrannus), Atlantic Silverside (Menidia menidia), Bay Anchovy (Anchoa mitchilli), mysids, and sevenspine bay shrimp (Crangon septemspinosa) (Scharf et al., 2004; L. Stehlik and senior author, unpubl. data).

Diet studies of small size classes $(<500 \mathrm{~mm}$ TL $)$ of predators indicate that age- 0 Atlantic Menhaden $(<200$ $\mathrm{mm}$ TL) are preferred prey that, with other small prey, reside in the Navesink River throughout the warmer months. Larger (>200 mm TL), energy rich age-1+ Atlantic Menhaden, consumed by the largest Bluefish and Striped Bass, are abundant in the river during late spring, but they migrate out of the tributary in June and July before returning again in early autumn (Scharf et al., 2004). Early summer egress of the largest Striped Bass and Bluefish ( $>500 \mathrm{~mm}$ TL) from the Navesink River coincided with the typical timing of egress for age-1+ Atlantic Menhaden and other large prey (L. Stehlik and senior author, unpubl. data). These large prey may be required by large fishes, particularly when warm temperatures increase metabolic demand.

Metabolic demand in ectotherms is regulated by environmental temperatures, as well as by body size (Hartman and Brandt, 1995; Brown, 2004; Sousa et al., 2010), and our GAMMs indicated that residence times of the 3 predators in the Navesink River were a function of the interaction between body size and water temperature. For all species, threshold temperatures for egress and breadths of temperatures associated with estuarine residence decreased with increasing body size. The largest age-1+ Striped Bass and Bluefish (>500 $\mathrm{mm}$ TL) released in the spring were likely to remain in the river only until temperatures exceeded $23^{\circ} \mathrm{C}$ in the early summer. Smaller Striped Bass were less sensitive than large fish and remained in the river over a broader range of warmer temperatures. Smaller age-1+ Bluefish were also more likely to be resident at warmer temperatures ranging from $23^{\circ} \mathrm{C}$ to $26^{\circ} \mathrm{C}$. Age-0 Bluefish remained in the estuary at the warmest temperatures recorded and were unlikely to leave until temperatures declined below $19^{\circ} \mathrm{C}$ during autumn. Finally, Weakfish also remained in the estuary when temperatures were warmest and were more likely to leave the river when temperatures declined below $23^{\circ} \mathrm{C}$ in the autumn. Smaller Weakfish, however, remained in the river longer and over a broader range of temperatures.
The relationships between estuarine residency time, body size, and environmental temperature that we observed are consistent with bioenergetic studies and metabolic theory (Gillooly et al., 2001; Brown, 2004; Harris et al., 2006; Sousa et al., 2010). The speciesand size-specific temperatures of estuarine residence and egress that we measured were extremely similar to temperatures and size-dependent scopes for growth reported by Steinberg (1994) and Hartman and Brandt (1995). In those studies, growth potential exceeded $2 \%$ of body weight per day at temperatures of $12-25^{\circ} \mathrm{C}$ (optimal $15^{\circ} \mathrm{C}$ ) for Striped Bass, $16-26^{\circ} \mathrm{C}$ (optimal $20^{\circ} \mathrm{C}$ ) for Bluefish and $20-29^{\circ} \mathrm{C}$ (optimal $23.5^{\circ} \mathrm{C}$ ) for Weakfish.

Smaller individuals generally had higher optimal temperatures for growth because metabolic demand and prey requirements are generally smaller for animals with small body sizes. For example, the thermal optima for age- $1+$ Bluefish was $\sim 20^{\circ} \mathrm{C}$, but growth potential for age-0 Bluefish reached a maximum at temperatures of $\sim 25-27^{\circ} \mathrm{C}$ (Steinberg, 1994; Hartman and Brandt, 1995; Scharf et al., 2006). Ranges of optimal temperatures for various performance measures are also generally broader for smaller, juvenile ectotherms (Freitas et al., 2010), and our GAMMs indicated that smaller fishes were more likely than larger fish to remain in the Navesink River over a broader range of temperatures. Because metabolic demand increases with temperature as well as body size, prey supply shortages are more likely to occur during the warmest summer months for large animals in small estuarine tributaries like the Navesink River.

Residence time and egress of the 3 studied predators also were related to the rate of freshwater discharge from the Swimming River into the Navesink River. On the basis of the 4 GAMMs that we constructed independently for the predators, we determined that animals were more likely to leave the small estuarine system when average daily freshwater discharge rates from the Swimming River fell below $\sim 2 \mathrm{~m}^{3} \mathrm{~s}^{-1}$ than when discharge rates were higher. High discharge events $\left(>50 \mathrm{~m}^{3} \mathrm{~s}^{-1}\right)$ also appeared to affect residencies of Striped Bass and, perhaps, age-1+ Bluefish. However, in contrast with this low discharge response, high discharge response thresholds varied by species. The predators that we tagged were euryhaline and probably did not respond behaviorally at the scale of the whole estuary to the direct physiological effects of increasing or high salinities. We hypothesize that the effects of low discharge on residence and egress were indirect through hydrographic processes that control the availability of prey resources that support the entire suite of predators that we tagged.

Variability in freshwater discharge is believed to affect estuarine fishes primarily by changing estuarine hydrodynamics that control prey resource availability. Interactions between freshwater discharge and tides control gravitational circulation in estuaries and the advection and concentration of the essential building blocks of estuarine food webs. As a result, estuaries 
are traps for autochthonous and allochthonous nutrients and organic matter from adjacent terrestrial and marine systems (MacCready and Geyer, 2010). Stable isotope studies indicate that estuarine food webs are supported by inputs of freshwater and terrestrial sources of nutrients and organic matter (Kostecki et al., 2010). It is assumed that discharge effects on estuarine hydrodynamics and nutrient transport ultimately concentrate high secondary production of zooplankton in estuarine regions where fresher and saltier waters converge (North and Houde, 2006; Baptista et al., 2010). These mechanisms are thought to produce a dome-shaped relationship between estuarine fish production and freshwater discharge (Dolbeth et al., 2010; and references therein).

In the Navesink River, tidal asymmetries produce a short-duration, high-velocity flood tide followed by a long, slow ebb (Chant and Stoner, 2001). During flood tides, particles are suspended and transported upstream. When freshwater discharge from the Swimming River is sufficient, the water column in the Navesink River stratifies during the ebb and particles accumulate in the central and upper reaches of this river. Finer particles and flocculants can remain in suspension in the upper Navesink River (Fig. 1., between locations B and $\mathrm{C}$ ), where a convergence zone is formed by the turbulent mixing of freshwater inflow from the Swimming River and tidal inflows of saltwater from Sandy Hook Bay and the Atlantic Ocean (Fugate and Chant, 2005).

In this area, Shaheen et al. (2001) reported high concentrations of the copepod Eurytemora affinis, an important constituent of estuarine food webs. We measured relatively sharp gradients in salinity and chlorophyll- $a$ and, compared with levels observed in other areas in our study, higher abundances of small fish prey, including Atlantic Silverside and age-0 Atlantic Menhaden in combined hydrographic and gillnet surveys (L. Stehlik and senior author, unpubl. data). Additionally, most of the predators that we tagged established home ranges in this region for days to weeks when temperatures in the upper estuary remained below thresholds associated with egress (L. Stehlik and senior author, unpubl. data; see also Scharf et al., 2004; Manderson et al. ${ }^{2}$ ).

Estuaries change from stratified to well-mixed states when freshwater discharge decreases and salinity stratification weakens to the point that estuarine Richardson numbers reach a range of 0.08-0.8 (Fischer, 1979; MacCready and Geyer, 2010). This transition occurs in the Navesink River when freshwater discharge from the Swimming River falls to $\sim 1 \mathrm{~m}^{3} \mathrm{~s}^{-1}$, $\left(\right.$ Chant $\left.^{3}\right)$,

\footnotetext{
2 Manderson, J. P., J. Pessutti, J. E. Rosendale, and B. Phelan. 2007. Estuarine habitat dynamics and telemetered movements of three pelagic fishes: Scale, complexity, behavioral flexibility and the development of an ecophysiological framework. ICES Council Meeting (C.M.) Documents 2007/G:02, $36 \mathrm{p}$.

${ }^{3}$ Chant, R. 2004. Personal commun. Institute of Coastal and Marine Science, Rutgers Univ., 71 Dudley Rd., New Brunswick, NJ 08901.
}

a discharge rate similar to the value at which all the predators we tagged were likely to leave this small estuary in New Jersey. We speculate that the relationship between predator egress and freshwater discharge reflects a shift from a partially mixed to a fully mixed estuarine state and the relaxation of physical mechanisms that control and concentrate the high primary and secondary productivity that supports the 3 studied predators in the upper reaches of this estuary.

\section{Conclusions}

Our analyses of residence time and egress of individual Striped Bass, Bluefish, and Weakfish in the Navesink River, New Jersey, indicate that small estuarine tributaries contain the habitat resources required to sustain juvenile and small adult stages of these 3 predators for relatively long periods of time but that the resources that regulate habitat suitability are ephemeral. Required resources include temperature, which regulates metabolic demand and predatory capacity in cold-blooded fishes (Magnuson et al., 1979; Neill et al., 1994). Summer temperatures in the Navesink River appeared to support smaller predators for longer durations than they did for larger fishes presumably because prey requirements increase with body size and temperature and because the small tributary is dominated by small rather than large prey during the warmest summer months.

Freshwater discharge also appeared to be a critical habitat resource that controlled residence time for animals in this estuary. We believe this relationship reflects the essential role that freshwater discharge plays in regulation of physical processes that both drive and concentrate the secondary productivity required to meet the prey resource requirements of the predators. Other factors that we were not able to measure effectively, particularly dissolved oxygen concentrations and human predation pressure, also may have influenced habitat suitability and the residence time and timing of egress of predators in this small estuarine system (Brady et al., 2009).

Because estuaries occur at the land-sea boundary, high-frequency variability in atmospheric temperature, precipitation, and wind is rapidly translated into variability in water temperature, freshwater discharge, dissolved oxygen, and other biophysical processes that determine estuarine habitat suitability. Changes in seasonal rates of warming, cooling, and precipitation that alter and reduce the persistence of suitable estuarine habitats should require animals to undertake more frequent, long-distance movements that are energetically costly. Conversely, long durations of suitable habitat conditions require fewer shifts in local home range (Martinho et al., 2009) and allow the allocation of resources to the life-history processes of growth and reproduction instead of long-distance movements. 
Increased movement costs should come at the expense of strategies that reduce predation risk and increase growth and reproduction rates. Changes in atmospheric forcing with climate change are coherent over spatial scales of $1000 \mathrm{~s}$ of kilometers (Hare and Able, 2007; Manderson, 2008; Shearman and Lentz, 2010). As a result, climate-driven changes in habitat and persistence should affect the energy budgets and survival of many individuals over broad areas. These effects should be translated across a level of ecological organization to affect the birth and death rates of regional fish populations.

\section{Literature cited}

Aarts, G., M. MacKenzie, B. McConnell, F. Mike, and J. Matthiopoulo.

2008. Estimating space-use and habitat preference from wildlife telemetry data. Ecography 31:140-160

Able, K. W.

2005. A re-examination of fish estuarine dependence: evidence for connectivity between estuarine and ocean habitats. Estuar. Coast. Shelf Sci. 64:5-17.

Able, K. W., and M. P. Fahay.

2010. Ecology of estuarine fishes: temperate waters of the western North Atlantic, 566 p. Johns Hopkins Univ. Press, Baltimore.

Anderson-Teixeira, K. J., V. M. Savage, A. P. Allen, and J. F. Gillooly.

2009. Allometry and metabolic scaling in ecology. In Encyclopedia of life sciences. John Wiley \& Sons, Ltd, Chichester, UK. [Available from http://www.els.net/WileyCDA/ElsArticle/refId-a0021222.html.]

Armsworth, P. R., and J. E. Roughgarden.

2005. The impact of directed versus random movement on population dynamics and biodiversity patterns. Am. Nat. 165:449-465.

Baptista, J., F. Martinho, M. Dolbeth, I. Viegas, H. Cabral, and M. Pardal.

2010. Effects of freshwater flow on the fish assemblage of the Mondego estuary (Portugal): comparison between drought and non-drought years. Mar. Freshw. Res. 61:490-501.

Belisle, M.

2005. Measuring landscape connectivity: the challenge of behavioral landscape ecology. Ecology 88:1988-1995.

Bennetts, R. E., J. D. Nichols, J.-D. Lebreton, R. Pradel, J. E.

Hines, and W. M. Kitchens.

2001. Methods for estimating dispersal probabilities and related parameters using marked animals. In Dispersal (J. Clobert, E. Danchin, A. A. Dhondt and J. D. Nichols, eds.), p. 3-17. Oxford Univ. Press, Oxford, UK.

Brady, D. C., D. M. Tuzzolino, and T. E. Targett.

2009. Behavioral responses of juvenile weakfish $(C y$ noscion regalis) to diel-cycling hypoxia: swimming speed, angular correlation, expected displacement, and effects of hypoxia acclimation. Can. J. Fish. Aquat. Sci. 66:415-424.

Brown, J. H.

2004. Toward a metabolic theory of ecology. Ecology 85:1771-1789.
Chant, R. J., and A. W. Stoner.

2001. Particle trapping in a stratified flood-dominated estuary. J. Mar. Res. 59:29-51.

Charnov, E. L.

1976. Optimal foraging: the marginal value theorem. Theor. Popul. Ecol. 9:129-136.

Chiarella, L. A., and D. O. Conover.

1990. Spawning season and first-year growth of adult bluefish from the New York Bight. Trans. Am. Fish. Soc. 119:455-462.

Dolbeth, M., F. Martinho, V. Freitas, S. Costa-Dias, J. Campos, and M. Pardal.

2010. Multi-year comparisons of fish recruitment, growth and production in two drought-affected Iberian estuaries. Mar. Freshw. Res. 61:1399-1415.

Fischer, H. B., E. J. List, R. C. Y. Koh, J. Imberger, and N. H. Brooks.

1979. Mixing in inland and coastal waters, 483 p. Academic Press, San Diego, CA.

Freitas, V., K. Cardoso, K. Lika, M. A. Peck, J. Campos, S. Kooijman, and H. W. van der Veer.

2010. Temperature tolerance and energetics: a dynamic energy budget-based comparison of North Atlantic marine species. Philos. Trans. R. Soc. Lond., B: Biol. Sci. 365:3553-3565.

Fugate, D. C., and R. J. Chant.

2005. Near-bottom shear stresses in a small, highly stratified estuary. J. Geophys. Res. 110:C03022.

Gillooly, J. F., J. H. Brown, G. B. West, V. M. Savage, and E.

L. Charnov.

2001. Effects of size and temperature on metabolic rate. Science 293:2248-2251.

Grothues, T. M., and K. W. Able.

2007. Scaling acoustic telemetry of bluefish in an estuarine observatory: detection and habitat use patterns. Trans. Am. Fish. Soc. 136:1511-1519.

Hagy, J. D.

2002. Eutrophication, hypoxia and trophic transfer efficiency in Chesapeake Bay. Ph.D. diss., 330 p. Univ. Maryland, College Park, MD.

Hare, J. A., and K. W. Able.

2007. Mechanistic links between climate and fisheries along the east coast of the United States: explaining population outbursts of Atlantic croaker (Micropogonias undulatus). Fish. Oceanogr. 16:31-45.

Harrington, D. P., and T. R. Fleming.

1982. A class of rank test procedures for censored survival data. Biometrika 69:553-566.

Harris, L., C. Duarte, and S. Nixon.

2006. Allometric laws and prediction in estuarine and coastal ecology. Estuar. Coasts 29:340-344.

Hartman, K. J., and S. B. Brandt.

1995. Comparative energetics and the development of bioenergetics models for sympatric estuarine piscivores. Can. J. Fish. Aquat. Sci. 52: 1647-1666

Johnson, J. C., J. J. Luczkovich, S. P. Borgatti, and T. A. B. Snijders.

2009. Using social network analysis tools in ecology: Markov process transition models applied to the seasonal trophic network dynamics of the Chesapeake Bay. Ecol. Model. 220:3133-3140.

Kostecki, C., F. Le Loc'h, J. M. Roussel, N. Desroy, D. Huteau, P. Riera, H. Le Bris, and O. Le Pape.

2010. Dynamics of an estuarine nursery ground: the spatio-temporal relationship between the river flow and 
the food web of the juvenile common sole (Solea solea, L.) as revealed by stable isotopes analysis. J. Sea Res. 64:54-60

Krause, A. E., K. A. Frank, D. M. Mason, R. E. Ulanowicz, and W. W. Taylor.

2003. Compartments revealed in food-web structure. Nature 426:282-285.

Livingston, R. J.

1987. Field sampling in estuaries: the relationship of scale to variability. Estuaries 10:194-207.

MacCready, P., and W. R. Geyer.

2010. Advances in estuarine physics. Annu. Rev. Mar. Sci. 3:35-58.

Magnuson, J. J., L. B. Crowder, and P. A. Medvick.

1979. Temperature as an ecological resource. Am. Zool. 19:331-343.

Manderson, J. P.

2008. The spatial scale of phase synchrony in winter flounder (Pseudopleuronectes americanus) production increased among southern New England nurseries in the 1990s. Can. J. Fish. Aquat. Sci. 65:340-351.

Manderson, J. P., J. Pessutti, C. Meise, D. Johnson, and P. Shaheen.

2003. Winter flounder settlement dynamics and the modification of settlement patterns by post-settlement processes in a NW Atlantic estuary. Mar. Ecol. Prog. Ser. 253:253-267.

Manderson, J. P., J. Pessutti, P. Shaheen, and F. Juanes.

2006. Dynamics of early juvenile winter flounder predation risk on a North West Atlantic estuarine nursery ground. Mar. Ecol. Prog. Ser. 329:249-265.

Manderson, J. P., B. A. Phelan, C. Meise, L. L. Stehlik, A. J. Bejda, J. Pessutti, L. Arlen, A. Draxler, and A. W. Stoner.

2002. Spatial dynamics of habitat suitability for the growth of newly settled winter flounder Pseudopleuronectes americanus in an estuarine nursery. Mar. Ecol. Prog. Ser. 228:227-239.

Mann, K. H.

2000. Ecology of coastal waters: with implications for management, $2^{\text {nd }}$ ed., 432 p. Blackwell Science, Inc., Malden, MA.

Martinho, F., M. Dolbeth, I. Viegas, C. M. Teixeira, H. N. Cabral, and M. A. Pardal.

2009. Environmental effects on the recruitment variability of nursery species. Estuar. Coast. Shelf Sci. 83:460-468.

Mather, M. E. F., K. H. Ferry, L. A. Deegan, and G. A. Nelson. 2009. Use of non-natal estuaries by migratory striped bass (Morone saxatilis) in summer. Fish. Bull. 107:329.

Munch, S. B., and D. O. Conover.

2000. Recruitment dynamics of bluefish (Pomatomus saltatrix) from Cape Hatteras to Cape Cod, 19731995. ICES J. Mar. Sci. 57:393-402.

Neill, W. H., J. M. Miller, H. W. Van Der Veer, and K. O. Winemiller.

1994. Ecophysiology of marine fish recruitment: a conceptual framework for understanding interannual variability. J. Sea Res. 32:135-152.

Ng, C., K. W. Able, and T. M. Grothues.

2007. Habitat use, site fidelity, and movement of adult striped bass in a southern New Jersey estuary based on mobile acoustic telemetry. Trans. Am. Fish. Soc. 136:1344-1355.
North, E. W., and E. D. Houde.

2006. Retention mechanisms of white perch (Morone americana) and striped bass (Morone saxatilis) earlylife stages in an estuarine turbidity maximum: an integrative fixed-location and mapping approach. Fish. Oceanogr. 15:429-450.

Pautzke, S. M., M. E. Mather, J. T. Finn, L. A. Deegan, and R. M. Muth.

2010. Seasonal use of a New England estuary by foraging contingents of migratory striped bass. Trans. Am. Fish. Soc. 139:257-269.

Peterson, M. S., M. R. Weber, M. L. Partyka, and S. T. Ross. 2007. Integrating in situ quantitative geographic information tools and size-specific laboratory-based growth zones in a dynamic river-mouth estuary. Mar. Freshw. Ecosys. 17:602-618.

$\mathrm{R}$ Core Team

2013. R: a language and environment for statistical computing. R Foundation for Statistical Computing, Vienna, Austria. [Available from http://www.R-project.org.]

Scharf, F. S., J. A. Buckel, K. A. Rose, and F. Juanes.

2006. Effects of variable prey and cohort dynamics on growth of young-of-the-year estuarine bluefish: evidence for interactions between spring- and summer-spawned cohorts. Trans. Am. Fish. Soc. 135:1266-1289.

Scharf, F. S., J. P. Manderson, M. C. Fabrizio, J. P. Pessutti, J. E. Rosendale, R. J. Chant, and A. J. Bejda.

2004. Seasonal and interannual patterns of distribution and diet of bluefish within a middle Atlantic Bight estuary in relation to abiotic and biotic factors. Estuaries 27: 426-436.

Shaheen, P. A., L. L. Stehlik, C. J. Meise, A. W. Stoner, J. P. Manderson, and D. L. Adams.

2001. Feeding behavior of newly settled winter flounder (Pseudopleuronectes americanus) on calanoid copepods. J. Exp. Mar. Biol. Ecol. 257:37-51.

Shearman, R. K., and S. J. Lentz.

2010. Long-term sea surface temperature variability along the U.S. East Coast. J. Phys. Oceanogr. 40:1004-1017.

Sousa, T., T. Domingos, J. C. Poggiale, and S. A. L. M. Kooijman. 2010. Dynamic energy budget theory restores coherence in biology. Philos. Trans. R. Soc. Lond., B: Biol. Sci. 365:3413-3428.

Steinberg, N. S.

1994. Young-of-the-year bluefish (Pomatomus saltatrix) consumption in the Hudson River estuary: a bioenergetic modeling approach. M.S. thesis, 100 p. State Univ. New York at Stony Brook, Stony Brook, NY.

Stoner, A. W., J. P. Manderson, and J. Pessutti.

2001. Spatially explicit analysis of estuarine habitat for juvenile winter flounder (Pseudopleuronectes americanus): combining generalized additive models and geographic information systems. Mar. Ecol. Prog. Ser. 213:253-271.

Taylor, D. L., R. Nichols, and K. W. Able.

2007. Habitat selection and quality for multiple cohorts of young-of-the-year bluefish (Pomatomus saltatrix): comparisons between estuarine and ocean beaches in southern New Jersey. Estuar. Coast. Shelf Sci. 73:667-679. 
Turnure, J. T.

2010. Estuarine habitat ecology of adult weakfish ( $C y$ noscion regalis): a multi-scale approach. M.S. thesis, 139 p. Rutgers, State Univ. New Jersey, New Brunswick, NJ.

Wingate, R. L., and D. H. Secor.

2007. Intercept telemetry of Hudson River striped bass resident contingent: migration and homing patterns. Trans. Am. Fish. Soc. 136:95-104.
Winkler, K., J. H. Rappole, and M. A. Ramos.

1995. The use of movement data as an assay of habitat quality. Oecologia 101:211-216.

Wood, S.

2006. Generalized additive models: an introduction with R. Chapman and Hall, Boca Raton, FL.

2012. gamm4: Generalized additive mixed models using mgev and lme4. $\mathrm{R}$ package, vers. 0.1-6. [Available from http://CRAN.R-project.org/package=gamm4.] 